\title{
QUESTIONS OF ACQUIRING PSYCHOMOTORIC SKILLS
}

\section{Jarmila HONZÍKOVÁ-Jan JANOVEC}

\begin{abstract}
The paper deals with teaching psychomotor skills, with possibilities and limits of such education, approaches of teachers to this education and with differences in the approaches themselves. Answer to question if there are any groups among the teachers which significantly differ in approaches to teaching in term of optional aims, methods and forms of teaching is investigated. Questionnaires focused on aims of teaching and also Q-methodology in sphere of methods and forms were used as the research methods. These surveys were carried out in terms of project Non-verbal creativity in vocational education - GAČR 406/07/0109 and project of the Internal Grant Agency of the Faculty of Education of UJEP Development of Competences in Pupils of Younger School Age in Sphere of Psychomotor Skills.
\end{abstract}

Key words: psychomotor skills, educational methods and forms, educational aims, Q-methodology.

\section{PROBLEMATIKA OSVOJOVÁNÍ PSYCHOMOTORICKÝCH DOVEDNOSTÍ}

Resumé: Článek se zamýšlí nad výukou psychomotorických dovedností, nad možnostmi této výuky, nad př́stupem učitelů $\mathrm{k}$ této výuce, nad rozdíly $\mathrm{v}$ těchto přístupech. Hledá odpověd’ na otázku, zda mezi učiteli praktických činností existují skupiny, jež se výrazně liší v př́stupu $\mathrm{k}$ výuce $\mathrm{z}$ hlediska volených cílů, metod a forem výuky. Jako výzkumných metod bylo použito dotazníkového šetření zaměřeného na cíle výuky a dále Q-metodologie $\mathrm{v}$ oblasti metod a forem. Tyto výzkumy byly provedeny v rámci projektu Nonverbální tvořivost v technické výchově - GAČR 406/07/0109 a projektu Interní grantové agentury PF UJEP Rozvoj kompetencí u žáků mladšího školního věku v oblasti psychomotorických dovedností.

Klíčová slova: psychomotorické dovednosti, vyučovací metody a formy, výukové cíle, Q-metodologie.

\section{1 Úvod}

Učení psychomotorickým dovednostem je jedním z hlavních úkolů předmětů technické výchovy a praktických činností. $\mathrm{Na}$ postupy učení psychomotorickým dovednostem existují $\mathrm{v}$ praxi dva protichůdné názory. Na jedné straně je to postup prostého napodobování a mnohonásobného opakování, na druhé straně postup, při kterém učitel vede žáky $\mathrm{k}$ tomu, aby při učení přemýšleli, využívali vědomostí, kontrolovali si průběh a výsledky své práce, analyzovali své chyby a předcházeli jim. Toto tvrzení je mezi odbornou veřejností všeobecně přijímáno, ale zatím bylo empiricky zkoumáno pouze okrajově.

\section{Psychomotorické učení}

V procesu osvojování psychomotorických dovedností probíhá několik fází, z nichž je nejdůležitější první, tzv. kognitivní fáze. Zanedbáním této fáze se ztíží další osvojování psychomotorické dovednosti. V průběhu tohoto počátečního stádia se žák seznamuje s činností, postupem a provedením. Velice důležitým momentem je zde názorná ukázka doplněná slovní instrukcí. Tato fáze je velice náročná pro vnímání, představy, pamět', myšlení a řeč (Čáp, Mareš, 2001). Ve druhé fázi se využívá získaných informací a provádí se první pokusy o danou činnost. Dbá se na kontrolu a sebekontrolu žáka, práci s chybami a zpětnou vazbu. Během poslední fáze žák postupuje samostatněji. Tato fáze je časově nejdelší. Stále má svůj význam názorná ukázka, slovní instrukce, vlastní cvičení, sebekontrola a kontrola, rozbor chyb a jejich odstraňování jinak řečeno zpětná vazba. Činnosti se zde automatizují.

Z metodického hlediska již $v$ minulosti vyvstaly problémy jak správně postupovat při osvojování psychomotorických činností. Tradiční postup spočíval na názorném předvedení, ukázce a následujícím napodobování. Na jedné straně docházelo $\mathrm{k}$ tak podrobnému instruování a rrízení žákovy činnosti, až se tlumila jeho samostatnost a na straně druhé byla ponechána př́lišs velká samostatnost žákům. Pro nás je důležité sloučit obojí, avšak v jiném rozsahu a formě 
u jednotlivých osob a dovedností. „Různé psychomotorické dovednosti vyžadují různý metodický postup“ (Č́a, Mareš, 2001, s. 381).

Při nácviku psychomotorických dovedností je nutné zvolit správný vyučovací postup:

- učení po částech nebo v celku - při nácviku složitějších pohybových činností je lepší postupovat po částech. Na druhé straně může časté opakování jednotlivých prvků narušit žákovu motivaci, a proto je zde vhodné spíše zvolit učení v celku. Náročná místa v činnosti je dobré oddělovat a procvičovat zvlášt' pomocí kombinace učení v celku a po částech.

- kvalita výsledků, přesnost nebo rychlost - zde velmi záleží na vhodně zvolené metodě. $\mathrm{V}$ některých případech je lepší nacvičovat v pomalejším tempu a snažit se o dosažení kvalitních výsledů, prevenci chyb a jejich odstranění. Někde je však lepší rychlejší tempo s vhodně rozvrženými přestávkami, které jsou využity pro kontrolu, ukázku, analýzu správnosti provedených činností a celkové zhodnocení.

Během hodin pracovních činností tyto metody ovlivňuje volba pracovního námětu. Pokud učitel zvolí př́liš složitý námět, který chce, aby žáci realizovali v časově omezené době, bude to vést ke spěchu a nepřesné práci žáků. Při osvojování nové psychomotorické dovednosti využíváme také transfer, což je podobná dovednost, kterou jsme si osvojili již dř́ve. Podobné zkušenosti, které žák získá v předešlých činnostech však mohou vést i k chybám, což nazýváme interference (Prunner, 2003). V tomto momentu je velice důležité, abychom žákům srovnali předchozí a novou činnost, aby si uvědomili, v čem je stará a nová činnost stejná nebo naopak rozdílná.

\section{Stanovení vyučovacích cílů při učení psychomotorickým dovednostem}

Pro identifikaci zpo̊sobu výuky psychomotorickým dovednostem je důležitá učitelova volba vzdělávacího cíle. Otázka, na níž byla hledána odpověd' pomocí dotazníkového šetření, zní následovně: Využivají učitelé jako vyučovací cíl při hodinách praktických činností a učení psychomotorickým dovednostem pouze imitaci a manipulaci, nebo také voli jako vyučovací cíl rozvoj tvořivosti, tzn. rozvíjeji užáků samostatné myšlení pomoci hledání vlastnich řě̌eni?

$\mathrm{Na}$ tuto otázku byla získána odpověd' po výzkumném šetření na základních školách, kde byl vybrán vzorek 70 respondentů z řad učitelů 1. stupně základních škol. Je zřejmé, že tyto výsledky nelze zobecňovat, ale i tak se lze domnívat, že vyjadřují určitý pohled na danou problematiku. Uvedené výsledky byly východiskem i důvodem pro realizaci níže uvedeného výzkumu pomocí Q-metodologie.

Manipulaci jako cíl formulují učitelé v senzomotorické oblasti:

- vždy -8 respondentů;

- často - 54 respondenti;

- někdy -8 respondentů;

- málokdy - 0 respondentů;

- $\quad$ nikdy -0 respondentů.

Imitaci jako cíl formulují učitelé v senzomotorické oblasti:

- vždy - 0 respondentů;

- často - 30 respondentů;

- někdy - 40 respondentů;

- málokdy - 0 respondentů;

- nikdy - 0 respondentů.

Adaptaci a tvořivost jako cíl formulují učitelé v senzomotorické oblasti:

- $\quad$ vždy -4 respondenti;

- $\quad$ často -8 respondentů;

- někdy -48 respondentů;

- málokdy - 10 respondentů;

- nikdy -0 respondentů.

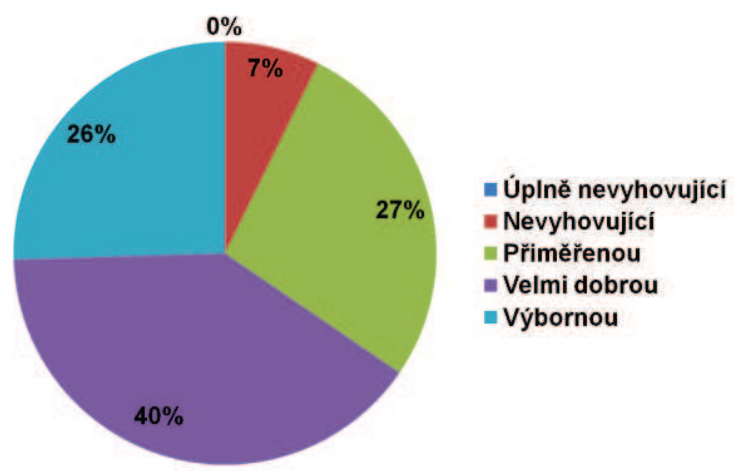

Graf 1. Adaptace a tvořivost jako vyučovací cíl

Jaké jsou postoje učitelů k formování vyučovacího cíle, $\mathrm{v}$ tomto případě adaptace a tvořivosti, jsme se zeptali 55 učitelů základních škol. Vyučující považují tento cíl - adaptace a tvořivost - z oblasti učení se senzomotorickým dovednostem za (graf. č.1): 
- úplně nevyhovující úroveň učení se - 0 respondenti̊;

- nevyhovující úroveň učení se - 4 respondenti;

- přiměřenou úroveň učení se - 15 respondentů;

- velmi dobrou úroveň učení se -22 respondentů;

- výbornou úroveň učení se - 14 respondentü;

- neumí se vyjádřit - 0 respondentů.

Výzkumné šetření ukázalo, že na našich školách při učení senzomotorickým dovednostem stále ještě převládá spíše způsob napodobování, tzn. imitace a manipulace. Poměrně vysokého procenta dosáhla jako cíle učení senzomotorickým dovednostem i tvořivost. Pokud jsme se ale zeptali učitelů, zda považují tvořivost za vyhovující úroveň učení se senzomotorickým dovednostem, nebyly již výsledky tak přesvědčivé. Zde je nutné připomenout, že každé vyučování by mělo žákům poskytnout dostatek prostoru pro tvořivou práci. Podmínek, které by mělo takovéto vyučování splňovat, lze stanovit hned několik - zajištění př́ležitosti pro tvořivou práci žáků, jejich podpora, oceňování jejich nápadů a myšlenek, poskytování dostatku času $\mathrm{k}$ přemýšlení nad problémy, k produkování představ a $\mathrm{k}$ rozvoji fantazie.

\section{Metody a formy při výuce psychomotorických dovedností}

Pro potvrzení původního předpokladu, že mezi učiteli existují dvě výrazné skupiny odlišující se prístupem $\mathrm{k}$ výuce psychomotorických dovedností metoda dotazníkového šetření vyhodnoceného pouze popisnou statistikou nepřináší validní a statisticky podložené výsledky. Pro další postup bylo zvoleno odchýlit se od kategorie cílu a zabývat se metodami a formami výuky. Lze předpokládat, že učitelova volba metod a forem je v praxi mnohem blíže uskutečněné výuce, dále vzhledem $\mathrm{k}$ počtu metod a forem bylo předpokládáno přesnější odlišení jednotlivých skupin zkoumaných učitelů a v neposlední řadě byla očekávána menší chyba výsledků vlivem zkresleného sebehodnocení respondentů a jejich výuky.

Ke zjištění používaných metod a forem výuky byla zvolena Q-metodologie. Ta umožňuje nejen zjištění absolutních hodnot zkoumaných proměnných, ale je rovněž efektivní metodou pro statistické zpracování, hledání podobností názorů u zkoumaného vzorku učitelů, respondentů výzkumu.

Tabulka 1. Metody a formy vyučování, které považují učitelé za nejvíce důležité

\begin{tabular}{|c|c|c|l|}
\hline Pořadí & $\overline{\boldsymbol{a}}$ & $\boldsymbol{\sigma}$ & Q-typ \\
\hline 1. & 7,29 & 2,19 & A33 motivační rozhovor \\
\hline 2. & 7,00 & 2,51 & A14 demonstrace praktické činnosti učitelem (např. pracovního postupu) \\
\hline 3. & 6,98 & 2,38 & A21 motivační demonstrace \\
\hline 4. & 6,95 & 2,05 & A31 motivační vyprávění \\
\hline 5. & 6,81 & 2,00 & A34 dialog (komunikace učitele, žáků a žáků navzájem) \\
\hline 6. & 6,55 & 2,12 & A32 rozhovor (komunikace učitele a žáků) \\
\hline
\end{tabular}

\section{Metodologie výzkumu}

Q-metodologie se úspěšně uživá ve výzkumech, v nichž se zjišt'uje, jak určitá skupina respondentů hodnotí danou množinu objekti̊, přičemž těchto objektů je velký počet (Kerlinger, 1973). V uváděném výzkumu bylo použito celkem 60 popisných karet pro oblast metod a forem výuky. Karty byly označeny písmenem " $A$ " a číslem př́slušným $\mathrm{k}$ jednomu ze šedesáti Q-typů. Tyto karty krátkým heslem vyjadřovaly charakteristiku šedesáti různých metod a forem vyučování užívaných při výuce manuálním dovednostem. Q-typy byly zvoleny autory článku a prakticky ověřeny $\mathrm{v}$ průběhu pilotáže u skupiny osmi učitelů. K mírné korekci došlo dvou odpovědí. Při samotném výzkumu byla respondentům předložena dvě otázka: "Přri výuce manuálních dovedností $v$ predmětu pracovni výchova preferuji/nepreferuji následujici metody a formy výuky". V souladu s metodikou výzkumu bylo požadováno, aby zkoumané osoby popisné karty rozdělily podle významu odpovědí do 11 skupin od nejdůležitější po nejméně důležitou. Pro umožnění a usnadnění zpracování statistických výsledků byla zvolena kvazinormální distribuce podle schématu 2-3-4- 
7-9-10-9-7-4-3-2, která přibližně odpovídá normálnímu rozdělení. Respondenti tedy řadily jednotlivé Q-typy do jedenácti skupin podle významu $\mathrm{s}$ předem předepsaným počtem odpovědí pro jednotlivé skupiny dle schématu. Jednotlivým polohám umístění Q-typů zleva doprava bylo při zpracování výsledků připisováno bodové hodnocení na stupnici: od deseti po nulu bodů.

Dalším důvodem využití Q-metodologie ve výzkumu je možnost zjištění, zda mezi hodnocením popisných karet u jednotlivých respondentů jsou podobnosti a jak jsou tyto podobnosti velké. $\mathrm{K}$ diferencovanému exaktnímu posouzení těsnosti vztahů mezi tříděním jednotlivých osob bylo využito Pearsonova korelačního koeficientu. Koeficienty korelace byly vypočítány pro všechny možné dvojice probandů a výsledky byly zapsány do korelační matice, jež pro její obsáhlost není možné uvést.

Tabulka 2. Metody a formy vyučování, které považují učitelé skupiny X za nejvíce důležité

\begin{tabular}{|c|c|c|l|}
\hline Pořadí & $\overline{\boldsymbol{a}}_{\boldsymbol{X}}$ & $\boldsymbol{\sigma}$ & Q-typ \\
\hline 1. & 8,68 & 1,45 & A21 motivační demonstrace \\
\hline 2. & 8,63 & 1,09 & A14 demonstrace praktické činnosti učitelem (např. pracovního postupu) \\
\hline 3. & 7,74 & 2,27 & A33 motivační rozhovor \\
\hline 4. & 7,47 & 1,96 & A31 motivační vyprávění \\
\hline 5. & 7,16 & 1,60 & A15 demonstrace hotových výrobků \\
\hline 6. & 7,11 & 1,65 & A30 vyprávění (poutavé sdělování příběhů týkajících se tématu) \\
\hline
\end{tabular}

Přesnější informace 0 typech třídění zkoumaných osob může přinést shluková analýza, jejímž cílem je přiřadit jednotky analýzy, $v$ našem př́padě se jedná o jednotlivé učitele, na základě podobnosti ke skupinám (Chráska, 2007). Pomocí shlukové analýzy lze získat informace, např. o tom zda se mezi hodnotícími osobami vyskytovaly určité typy osob, které mají na hodnocení předložených Q-typů podobné názory. Pro identifikaci takovýchto skupin bylo ve výzkumu užito metody k-průměrů.

\section{Výsledky výzkumu}

Výzkumného šetření se zúčastnilo 42 učitelů 1. st. ZŠ z Ústeckého kraje. Doba, po níž mohli zkoumaní učitelé třídit karty do skupin, nebyla během administrace metody omezena. Nejprve bylo použito ukazatelů popisné statistiky, vyčísleny byly aritmetické průměry $\bar{a}$, kterých jednotlivé Q-typy dosáhly a směrodatná odchylka $\sigma$. Metody a formy vyučovaní, které učitelé považují za nejdůležitější při vlastní výuce manuálním dovednostem jsou uvedeny $\mathrm{v}$ tabulce 1 . Za překvapivé $\mathrm{z}$ hlediska zkoumaného problému je možné považovat umístění dialogických a motivačních metod před metodami př́mo souvisejícími $\mathrm{s}$ manuálními činnostmi, i když relativně velká směrodatná odchylka vypovídá o větších rozdílech v názorech na důležitost těchto Q-typů.
Pro zjištění různých typů učitelů z hlediska jejich názoru na významnost metod a forem vyučování manuálním dovednostem byla vytvořena korelační matice. Již z ní byla zřejmá podobnost názorů u dvou skupin - shluků respondentů, projevující se poměrně velkou hodnotou korelačního koeficientu. Metoda k-průměrů přinesla přesnější určení těchto skupin $\mathrm{z}$ hlediska jejich zástupců, kdy početnější skupina nazvaná $X$ má 19 respondentů a v méně početné skupině $Y$ bylo zjištěno 12 respondentů.

U obou skupin byly vyhodnoceny aritmetické průměry dosažené u jednotlivých Q-typů a př́slušné směrodatné odchylky. Pořadí a hodnoty získané pro prvních šest Q-typů u jednotlivých skupin prezentují tabulky 2 a 3 .

Přestože přesnější vymezení těchto dvou skupin bude vyžadovat podrobnější zkoumání a interpretace výsledků si vyžádá větší pozornost, lze konstatovat určité závěry. Respondenti skupiny $X$ preferují ve výuce manuálních dovedností především nácvik pracovních činností po instruktáži učitele, za důležité považují demonstraci, nejen praktické činnosti ale i finálního výrobku. Důraz kladou na motivaci žáka učitelem a z hlediska forem dávají přednost frontálnímu vyučování. Naopak respondenti skupiny $Y$ upřednostňují projektové a problémové vyučování, některé relativně nové metody, napřr. brainstorming a metody situační a simulační. Motivují především prostřednictvím 
rozhovoru a z hlediska forem preferují vyučování skupinové.

Poměrně výrazný rozdíl mezi oběma skupinami se projevuje v názoru jejich členů na projektové vyučování. Tabulka 4 zobrazuje jednotlivé, do jisté míry teoretické, možnosti uspořádání projektového vyučování. Vyčísleny byly aritmetické průměry, rozdíl mezi nimi, hodnota testového kritéria a statistická významnost. Pro testování statistické významnosti rozdílů průměrů ukazatelů sektorů bylo použito Studentova t-testu. V př́ípadech, kdy normalita statistických souborů nebyla potvrzena, vycházelo se při rozhodování o přijetí, či zamítnutí statistické významnosti rozdílu z výsledků neparametrického testu Manna a Whitneye. Z hlediska pořadí je zřejmé, že názory těchto dvou skupin jsou takřka protichůdné. Velmi významné a statisticky potvrzené rozdíly se projevují u projektů, kdy žáci navrhují celkový postup řešení. Zatímco učitelé skupiny $X$ je řadí do druhé poloviny preferovaných metod, u učitelů skupiny $\mathrm{Y}$ patří mezi velmi preferované a obsazují přední místa i v porovnání s ostatními metodami.

Tabulka 3. Metody a formy vyučování, které považují učitelé skupiny Y za nejvíce důležité

\begin{tabular}{|c|c|c|l|}
\hline Pořadí & $\overline{\boldsymbol{a}}_{\boldsymbol{Y}}$ & $\boldsymbol{\sigma}$ & Q-typ \\
\hline 1. & 7,83 & 1,99 & A35 diskuze (rozhovor učitele a žáků za účelem obhájení názoru) \\
\hline 2. & 7,58 & 1,75 & A33 motivační rozhovor \\
\hline 3. & 7,08 & 1,98 & A56 skupinové vyučování \\
\hline 4. & 7,00 & 2,24 & A9 projekt, žáci navrhují postup řešení a dílčí kroky řeší bez pomoci učitele \\
\hline 5. & 6,92 & 1,66 & A7 projekt, žáci navrhují postup řešení a dílčí kroky instruuje učitel \\
\hline 6. & 6,92 & 1,61 & A34 dialog (komunikace učitele, žáků a žákủ navzájem) \\
\hline
\end{tabular}

Výzkumné šetření není dosud ukončeno, zpracovaná data korelací jsou v pásmu statistické významnosti, avšak je třeba podrobnější analýzy získaných údajů a především jejich důkladná interpretace. Přesto lze konstatovat, existenci dvou významně odlišných skupin učitelů, kteří se odlišují zejména preferencemi při volbě metod a forem výuky manuálních dovedností. Toto se projevuje statisticky významně odlišným př́stupem $\mathrm{k}$ projektovému vyučování, jako výraznému prvku podporujícímu tvořivost žáků, ale i při volbě některých témat výuky - žákovských výrobků.

Tabulka 4. Pořadí Q-typů u skupin $\mathrm{X}$ a $\mathrm{Y}$ ve vztahu k projektovému vyučování

\begin{tabular}{|l|c|c|c|c|c|c|c|}
\hline Q-typ & $\mathrm{X}_{\text {poradi }}$ & $\mathrm{Y}_{\text {por̆adi }}$ & $\bar{a}_{X}$ & $\bar{a}_{Y}$ & $\begin{array}{c}\bar{a}_{X}- \\
\overline{a_{Y}}\end{array}$ & $t$ & $p$ \\
\hline $\begin{array}{l}\text { A9 projekt, kdy žáci navrhují celkový } \\
\text { postup řešení a dílčí kroky řeší bez } \\
\text { pomoci učitele }\end{array}$ & 42. & 4. & 4,26 & 7,00 & $-2,74$ & 3,56 & $<0,01$ \\
\hline $\begin{array}{l}\text { A8 projekt, kdy žáci navrhují celkový } \\
\text { postup řešení a s pomocí učitele řeší dílčí } \\
\text { kroky }\end{array}$ & 44. & 13. & 4,16 & 6,17 & $-2,01$ & 4,23 & $<0,01$ \\
\hline $\begin{array}{l}\text { A7 projekt, kdy žáci navrhují celkový } \\
\text { postup řešení a dílč́ kroky instruuje učitel }\end{array}$ & 40. & 5. & 4,32 & 6,92 & $-2,60$ & 4,46 & $<0,01$ \\
\hline $\begin{array}{l}\text { A6 projekt, kdy učitel navrhuje celkový } \\
\text { postup řešení a dílč́ kroky (bez } \\
\text { instruktáže) řeší žáci }\end{array}$ & 50. & 39. & 3,74 & 4,58 & $-0,85$ & - & - \\
\hline $\begin{array}{l}\text { A5 projekt, kdy učitel navrhuje celkový } \\
\text { postup řešení a dílč́ kroky po instruktáži } \\
\text { řš́ žáci }\end{array}$ & 21. & 34. & 5,58 & 4,75 & 0,83 & - & - \\
\hline $\begin{array}{l}\text { A4 projekt, kdy učitel navrhuje celkový } \\
\text { postup řešení i jednotlivé jeho kroky }\end{array}$ & 28. & 53. & 5,16 & 3,17 & 1,99 & 2,22 & $<0,05$ \\
\hline
\end{tabular}




\section{Závěr}

Uvedené výzkumné šetření ukázalo, že naše pedagogická veřejnost vykazuje určitou, celkem uspokojivou úroveň tvořivých schopností, použivá různé metody a formy práce. Pedagogická tvořivost se ovšem projevuje především tvořivou prací se vzdělávacím obsahem, méně již v oblasti cílů, ale i forem a metod práce. Projektové a problémové metody umožňují žákům určitou seberealizaci, možnost uplatnění svých vlastních názorů, umět si zorganizovat práci, naučit se pracovat týmově. Tyto metody zároveň umožňují spojení teorie a praxe, myšlení a proživání, což některé jiné metody neumožňují. Proto lze považovat problémové a projektové metody zároveň za velmi důležité při učení senzomotorickým dovednostem. Každé vyučování by mělo žákům poskytnout dostatek prostoru pro tvořivou práci.

Vzhledem kfaktu, že volba vyučovací strategie představuje specifické modelové situace, které jsou žáky mnohdy vnímány jako nezvládnutelné, tak řízením učitele bude žák veden $\mathrm{k}$ překonávání těchto obav, a tím i k postupnému ověřování svých možností a kompetentností, přičemž bude zároveň stimulován $\mathrm{k}$ využití a rozvoji svých zdrojů ke zvládání požadavků a následnému růstu seberegulace. Tím je možno rozvíjet vzájemnou důvěru učitele a žáků, stejně jako komunikaci s ostatními při modelových situacích, jejichž řešení vyžaduje vzájemnou spolupráci a komunikaci.

\section{Literatura}

[1] BADEGRUBER, B. Otevřené učení v 28 blocích. Praha : Portál, 1997.

[2] BEZJAK, J. Project learning of model PUDBJ - from idea to the product. Klagenfurt: LVM for Verlag S. Novak, 2009. 74 f., ilustr. ISBN 978-961-6397-11-7. [COBISS.SI-ID245920768] [3] ČÁP, J., MAREŠ, J. Psychologie pro učitele. Praha : Portál, 2001. ISBN 80-7178-463-X.

[4] GRECA, I., M.; MARCO, A. Mental models, conceptual models, and modelling. Intenatinional Journal of Science Education. roč. 22, č.1, s.111, 2000, ISSN 09500693.

[5] HLAVSA, J. Psychologické problémy výchovy k tvořivosti. Praha : 1981.

[6] HONZÍKOVÁ, J. Netradičně v pracovní výchově. Plzeň: Krajské centrum vzdělávání a Jazyková škola, 2005. - 241 s. +CD - ISBN 807020-149-5.
[7] HONZÍKOVÁ, J.; NOVOTNÝ, J. Projektové a problémové metody $\mathrm{V}$ praxi. In. e-PEDAGOGIUM. Vědecko - pedagogický časopis. Olomouc: Pedagogická fakulta UP, 2006. ISSN 1213-7499, tištěná forma: ISSN 1213-7758. - Roč. 4., č. 2/2006. (str. 28 - 40) Dostupné na internetu: http://epedagog.upol.cz.

[8] CHRÁSKA, M. Metody pedagogického výzkumu. Základy kvantitativního výzkumu. Praha: Grada, 2007. ISBN 978-80-247-1369-4.

[9] JANOVEC, J., HEŘMANOVÁ, V. Rozvíjení kompetencí učitelů primárního vzdělávání v oblasti Člověk a svět práce se zaměřením na psychomotorické dovednosti žáků. In: Technológie vzdelávania $v$ príprave učitelov prírodovedných a technických predmetov. Prešov: Prešovská univerzita v Prešove, 2011, s. 156-160. ISBN 978-80-555-0438-4.

[10] KERLINGER, F. Základy výzkumu chování. Praha : Academia, 1973.

[11] MIKLOŠÍKOVÁ, M. Kreativita a učitelství odborných předmětů. Ostrava: VŠB, 2009. ISSN 978-80-248-1952-5.

[12] PRUNNER, P. a kol. Vybrané kapitoly z pedagogické psychologie. Plzeň: ZČU, 2003. ISBN 80-7082-979-6.

[13] ŠPIČKOVÁ, K. Pracovní činnosti na 1. stupni ZŠ a jejich využití pro rozvoj psychomotorických dovedností. Diplomová práce. Plzeň: ZČU, FPE, 2007.

Doc. PaedDr. Jarmila Honzíková, Ph.D.

Západočeská univerzita v Plzni

Fakulta pedagogická

Katedra matematiky, fyziky a technické

výchovy

Klatovská 51

30000 Plzeň

Česká republika

Tel. +420 377636503

E-mail: jhonziko@kmt.zcu.cz

Www pracoviště: http://www.zcu.cz/fpe/kmt

Mgr. Jan Janovec, Ph.D.

Univerzita J. E. Purkyně

Pedagogická fakulta

Katedra preprimárního a primárního

vzděláváni

Hořeni 13

40096 Ústí nad Labem

Česká republika

Tel. +420 475282155

E-mail: jan.janovec@ujep.cz

Www pracoviště: http://pf.ujep.cz 